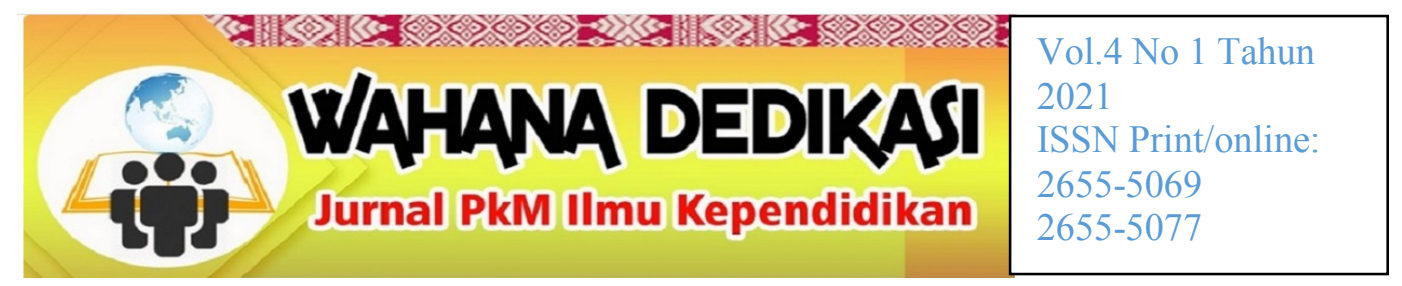

\title{
HORTIKULTURA: SOLUSI MENINGKATKAN EKONOMI MASYARAKAT PEDESAAN
}

\author{
Khafid ismail ${ }^{1}$, Muhamad Nanang Rifa' ${ }^{2}{ }^{2}$, Siti Afifah $^{3}$ \\ Muhammad Zainuddin Afas ${ }^{4}$ Rusmiati $^{5}$ \\ STKIP Nurul Huda $a^{l, 2,3,4,5}$ \\ khafid@stkipnurulhuda.ac.id ${ }^{1}$, nanang@stkipnurulhuda.ac.id ${ }^{2}$, afifah@stkipnurulhuda.ac.id ${ }^{3}$, \\ afas@stkipnurulhuda.ac.id ${ }^{4}$, rusmiati@stkipnurulhuda.ac.id5
}

\begin{abstract}
Abstrak
PKM ini ditujukan untuk meningkatkan pengetahuan sekaligus keterampilan terhadap kelompok masyarakat petani hortikultura yang terletak di Desa Kurungan Nyawa 1 Kabupaten OKU Timur. PKM ini di lakukan untuk pendampingan kepada masyarakat petani hortikultura terutama dalam hal: peningkatan produksi dan manajemen usaha. Untuk mencapai tujuan tersebut, PKM yang dilaksanakan mulai Oktober hingga Desember 2020 menggunakan metode pelatihan dan pendampingan. Adapun transfer IPTEK dalam kegiatan pelatihan yang telah digelar yaitu: teknik budidaya, teknik penanganan hama penyakit, strategi pemesaran dan manajmen usaha. Hasil PKM ini menunjukkan bahwa anggota dari kelompok petani hortikultura memahami teknik-teknik budidaya dan pemilihan varietas yang unggul, Teknik perawatan dan penanggulangan penyakit pada tanaman, dan juga Teknik manajemen usaha.
\end{abstract}

Kata kunci:petani, hortikultura, manajemen usaha, produksi

Artikel disetujui tanggal:30-05-2021

Corresponden Author:Khafid Ismail e-mail: khafid@stkipnurulhuda.ac.id

DOI: http://dx.doi.org/10.31851/dedikasi.v4i1.5484doi

PENDAHULUAN

Usaha pertanian memiliki

peran penting bagi perekonomian

nasional. Pada tahun 2020 Badan

Pusat Statistik (BPS) pusat merilis

PDB sector pertanian menjadi

penyumbang tertinggi terhadap

pertumbuhan ekonomi nasional pada

triwulan II 2020 yang mengalami

penurunan sebesar $4,19 \%$ dan secara

year on year (yoy) turun $5,32 \%$. PDB pertanian tumbuh sebesar 16,24\% pada triwulan-II 2020, yang artinya dari sector pertanian tetap menyumbangkan kontribusi terhadap pertumbuhan ekonomi nasional sebesar 2,19\% (Dirjen Hortikultura: 2021). Dilansir dari salah satu media elektronik yaitu Liputan 6, selama pandemi, serapan tenaga kerja sector pertanian tumbuh sebesar $2,23 \%$. Pandemic ovid-19 ini telah membawa 


\section{W/AHANA DEDIKASI}

disrupsipada sektor ketenagakerjaan nasional, akibatnya 29,12 juta orang penduduk usian produktif jadi terdampak. Namun dari sektor pertanian mampu menjadi penolong, terbukti bahwa serapan tenaga kerja terserap sebesar 2,23 \% dan bisa menjadi pendongkrak perekonomian nasional.

Dari sinilah terlihat bahwa sektor pertanian yang bersifat padat karya, menggunakan teknologi yang sederhana dan mudah dipahami mampu menjadi solusi masyarakat untuk bekerja sesuai dengan kemampuannya masing-masing khususnya bagi masyarakat pedesaan. Peran usaha pertanian terbukti mampu bertahan dan menyerap tenaga kerja akibat pandemi karena adanya wabah virus covid-19 sejak tahun 2019 sampai sekarang.

Seiring dengan semakin membaiknya tingkat perekonomian di seluruh kabupaten di provinsi Sumatera Selatan, OKU Timur merupakan salah satu provinsi yang tidak boleh di pandang sebelah mata dalam hal produk pertanian yang di hasilkan oleh masyarakat yang merupakan salah satu lumbung pangan bagi wilayah sekitarnya. Selain dari beragam varietas padi yang di hasilkan, OKU Timur juga merupakan penghasil berbagai jenis tanaman hortikultura terutama tanaman sayuran.

Dalam upaya meningkatkan produksi dari berbagai komoditas tanaman pertanian di Kabupaten Ogan Komering Ulu Timur masih terdapat peluang yang cukup besar, yaitu masih tersedia areal pertanian dan lahan potensial yang belum dimanfaatkan secara optimal, seperti lahan kering / rawa lebak; masih terdapat kesenjangan antara produktivitas riil di tingkat usahatani dengan produktivitas potensi, yaitu berkisar 10-100 \%; serta masih terdapat kesenjangan produktivitas dan mutu yang cukup besar.

Adanya

berbagai permasalahan yang sangat kompleks yang dihadapi oleh para petani hortikultura di Kabupaten OKU Timur khususnya Desa Kurungan Nyawa 1, membuat usahatani di Desa Kurungan Nyawa 1 sulit untuk berkembang. Oleh karena itu, PKM 


\section{W/AHANA DEDIKASI}

ini bertujuan untuk merumuskan strategi pengembangan kelompok usahatani di bidang hortikultura di Desa Kurungan Nyawa 1.

\section{BAHAN DAN METODE}

Pelaksanaan kegiatan PKM ini dilakukan denagn metode kaji tindak partisipatif, yaitu dengan melakukan identifikasi dan analisis situasi tentang permasalahan yang di hadapi para petani hortikultura. Selanjutnya tahapan yang dilakukan yaitu memberikan solusi, berupa pelatihan, dan pendampingan kepada para petani. Tahapan pelaksanaan PKM adalah sebagai berikut:

Identifikasi Baseline ; Produktivitas hasil pertanian hortikultura yang belum optimal. (2) Identifikasi permasalahan ; produk belum dipasarkan secara maksimal. (3) Penentuan solusi yang ditawarkan ; Pemberian pengetahuan tentang manajeman usaha dan akuntansi keuangan. (4) Pelaksanaan PKM ; Pendampingan kepada petani dalam hal manajemen usaha dan manajemen keuangan. (5) Monitoring dan
Evaluasi; Petani mampu meningkatkan produktivitas dan kualitas hasil pertanian.

Sedangkan metode pelaksanaan kegiatan PKM disusun sebagai berikut ; (1) Sosialisasi program (2) Pelatihan dan pendampingan (3) Evaluasi kegiatan.

\section{HASIL DAN PEMBAHASAN}

Pada tahap ini, merupakan pelaksanaan solusi yang ditwarkan untuk memecahkan permasalahan yang di hadapai para petani hortikultura. Adapun pelaksanaan kegiatan pengapdian kepada masyarakat di awali dengan kegiatan sosialisasi pada bulan Oktober 2020 yang bertempat di kediaman salah satu petani. Kegiatan disusn dalam bentuk Forum Discussion Group (FGD) antara tim PKM dengan kelompok petani hortikultura. Pertemuan ini di hadiri oleh 19 orang petani.

Kegiatan sosialisasi bertujuan menjelaskan rencana kegiatan PKM sesuai dengan analisis situasi yang dilakukan pengapdi. Dijelaskan juga rencana tahap-tahap PKM yang akan 


\section{W/AHANA DEDIKASI}

dilaksanakan. Setelah itu dilakukan diskusi untuk membahas rencana pelaksanaan PKM. Hasil diskusi diperoleh kesepakatan bahwa di bentuklah kelompok petani hortikultura, yang memiliki tujuan dan misi untuk maju Bersama.Tahap selanjutnya dari kegiatan PKM adalah pelaksanaan pendampingan dalam hal manajemen usahatani dan manajemen keuangan bagi kelompok petani hortikultura. Berikut kegiatan pelatihan dan pendampingan:

PKM yang dilakukan menjadi alternatif yang sangat berdampak terhadap kemajuan dan kemandirian para petani, dari modal awal (Rachmawati et al, 2018) sebagai kas kelompok sebesar Rp.5.000.000,00 sekarang sudah menjadi sekitar Rp.20.000.000,00. Serta meningkatkan produksi hasil pertanian setiap tanaman yang di budidaya oleh petani, diantaranya produksi daun bawang yang meningkat $70 \%$ dari sebelumya, tanaman sawi hijau meningkat $65 \%$, produksi jagung manis meningkat $80 \%$, dan juga di ikuti oleh produktivitas hasil pertanian yang lain.

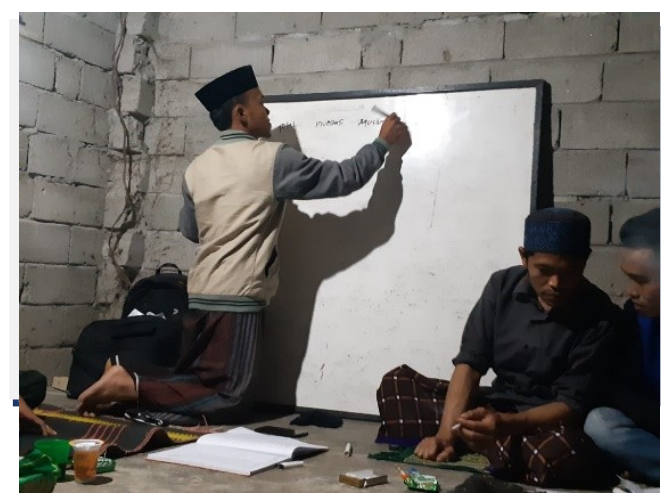

Gambar 1. Kegiatan Bimtek dan FGD

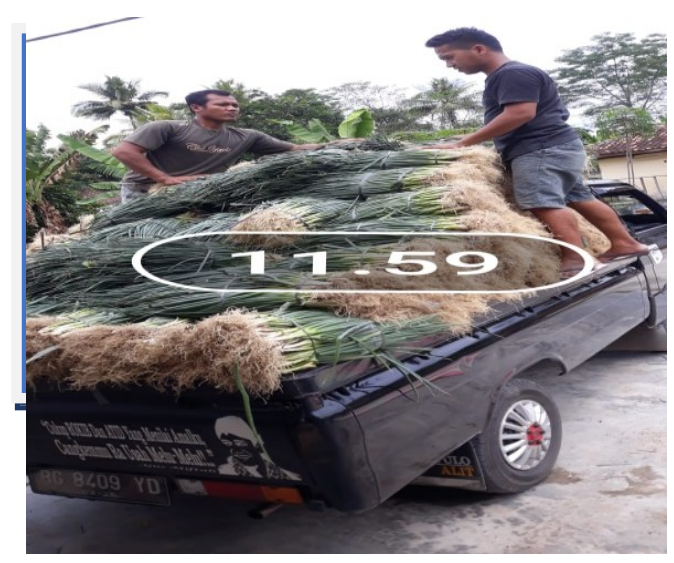

Gambar 2. Hasil Produksi Daun Bawang

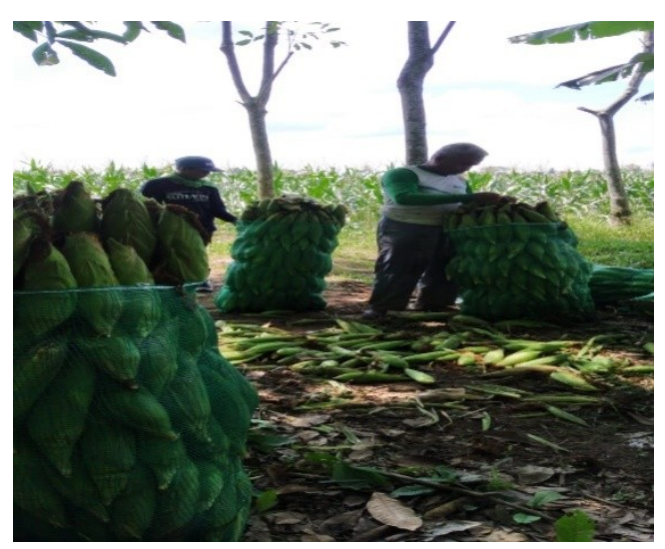




\section{W/AHANA DEDIKASI}

Gambar 2. Hasil Produksi Jagung

Manis

\section{KESIMPULAN}

Usaha tani di Desa Kurungan

Nyawa 1 memiliki potensi untuk dikembangkan. Usaha ini masih memerlukan pembinaan dari berbagai pihak. Tidak hanya dari pemerintah, pendampingan juga harus dilakukan juga dari pihak akademisi, tujuannya agar produktivitas hasil pertanian hortikultura meningkat, pengelolaan keuangan yang benar, serta berimbas pada meingkatnya serapan tenaga kerja dan perekonomian masyarakat pedesaan.

\section{DAFTAR PUSTAKA}

Adiputra, Andre Kussuma \& Dewi Ngaisyah (2020). "Peningkatan Kemampuan Pemasaran Kelompok Ibu-Ibu PKK Desa Kanigoro): Jurnal ABDIMAS UNNES.

Apriyanto, M., Oklianda, A., Putra, D. D., \& Warmi, A. (2021, February). Student Responses During Online Learning in the Covid-19 Pandemic Period. In Journal of Physics: Conference Series (Vol. 1764, No. 1, p. 012125). IOP Publishing.

Bisnis Liputan 6 (2020). Selama Pandemi, Serapan Teaga Kerja
Sektor Pertanian Tumbuh 2,23 Persen.

Dinas Pertanian Tanaman Pangan, Perikanan dan Peternakan Kab. OKU Timur (2006)Pertanian Ogan Komering Ulu Timur (okutimurkab.go.id) (diakses 20 April 2021).

Direktorat Jenderal Hortikultura (2020). Sektor Pertanian Tumbuh Paling Tinggi.

Rachmawati, D. W., Gunawan, H., Toyib, M., Aradea, R., \& Januardi, J. (2018). Kiprah Tenaga Pendidik Ekonomi/Akuntansi Dalam Mengaplikasikan Kompetensi Di Keluarga, Masyarakat, Organisasi Dan Dunia Kerja. WAHANA DEDIKASI, 1(2). 